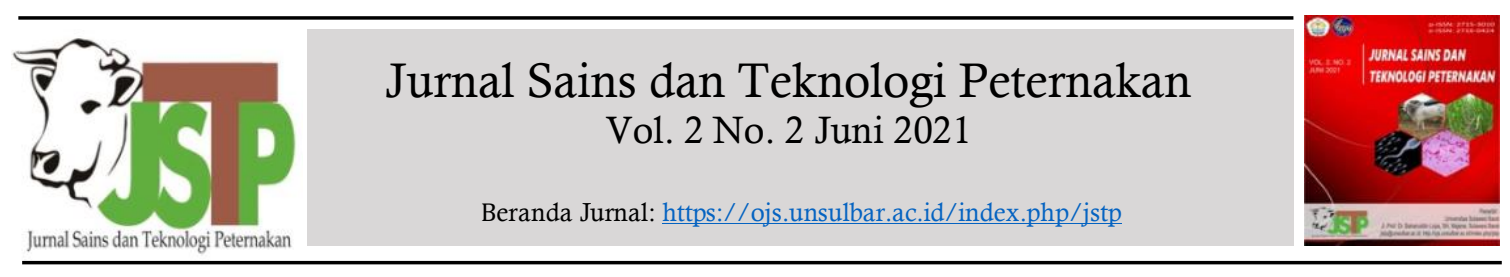

\title{
Sikap Konsumen terhadap Produk Kerupuk Dangke Merek Melona dan Tanpa Merek di Kecamatan Cendana, Enrekang
}

\author{
(Consumer Attitude towards Dangke Crackers Products of Melona Brand and Without Brand in \\ Cendana District, Enrekang)
}

Nur Aulia ${ }^{1}$, St. Aisyah R ${ }^{1 *}$, Sahlan ${ }^{1}$, Sitti Khadijah Yahya Hiola ${ }^{1}$
${ }^{1}$ Program Studi Agribisnis, Fakultas Pertanian, Universitas Muhammadiyah Makassar, J1. Sultan Alauddin No.
259, Gn. Sari, Kecamatan Rappocini, Makassar, Sulawesi Selatan 90221 .

A R T I C L E I N F O

Received: 26 April 2021

Accepted: 31 Mei 2021

*Corresponding author

st.aisyah@unismuh.ac.id

Keywords:

Costumer attitudes

Dangke crackers

Product attributes
Kata Kunci:

Atribut produk

Kerupuk dangke

Sikap konsumen

\section{A B S T R A C T}

The purpose of this study was to determine the consumer attitudes towards the product attributes of dangke crackers in Cendana District, Enrekang. The sampling technique used an accidental sampling of 50 consumers. This study uses primary and secondary data. The data were collected using observation, documentation, and interviews. The data analysis in this study was the Fishbein Multi-attribute analysis. The results showed the total value of consumer attitudes $\left(A_{o}\right)$ of the Melona brand and without the brand, respectively 68.38 and 65.03 . The packaging was an excellent attribute of the Melona brand. Thus, overall consumers were more satisfied with the Melona brand of dangke cracker products than unbranded dangke cracker products.

\section{A B S T R A K}

Tujuan penelitian ini yaitu untuk mengetahui sikap konsumen terhadap atribut produk kerupuk dangke di Kecamatan Cendana, Enrekang. Teknik pengambilan sampel menggunakan accidental sampling sebanyak 50 orang. Penelitian ini menggunakan sumber data primer dan data sekunder. Metode pengumpulan data dengan cara observasi, dokumentasi dan wawancara. Analisis data dalam penelitian ini yaitu analisis Multiatribut Fishbein. Hasil Penelitian menunjukkan nilai total sikap konsumen $\left(A_{o}\right)$ produk kerupuk dangke merek Melona dan tanpa merek masing-masing 68,38 dan 65,03 . Kemasan merupakan atribut unggulan kerupuk dangke Merek Melona. Secara keseluruhan konsumen lebih puas terhadap produk kerupuk dangke merek Melona dari pada produk kerupuk dangke tanpa merek.

(C) Jurnal Sains dan Teknologi Peternakan Vol 2(2) Juni 2021

p-ISSN: 2715-3010 | e-ISSN: 2716-0424

\section{Pendahuluan}

Salah satu alternatif program terobosan dalam pembangunan kawasan agribisnis berbasis peternakan yaitu untuk meningkatkan pendapatan dan kesejahteraan (Suyudi, Nuryaman, \& Erfan, 2016). Usaha peternakan sapi perah adalah salah satu usaha subsektor peternakan yang sangat menjanjikan dan peluangnya masih terbuka secara luas. Prospek pengembangan saat ini sudah diarahkan pada wilayah luar Jawa akibat daya dukung pakan di Pulau Jawa sudah mengalami keterbatasan. Kondisi demikian merupakan pertimbangan dalam rekomendasi kebijakan pengembangan sapi perah di luar Pulau Jawa, dalam mendukung kebutuhan susu nasional dalam mengurangi impor. Prospek daya dukung wilayah (lahan usaha) diluar Pulau Jawa masih tersedia luas yang hal tersebut memberikan kontribusi yang 
besar dalam pengembangan usaha peternakan terrnasuk sapi perah (Priyanto, 2018).

Provinsi Sulawesi Selatan merupakan salah satu daerah di luar Pulau Jawa yang ditunjuk Direktorat Jenderal Peternakan dan Kesehatan Hewan dalam pengembangan sapi perah. Kabupaten Enrekang merupakan salah satu kabupaten yang terkenal dengan peternakan sapi perah tradisionalnya. Kecamatan Cendana merupakan kecamatan yang memiliki populasi sapi perah terbanyak di Kabupaten Enrekang. Seiring dengan besarnya populasi sapi perah di Kabupaten Enrekang, maka banyak bermunculan moda produksi dari usaha sapi perah seperti: usaha pengolahan dangke, usaha penjualan sapi dan usaha pengolahan limbah yang hadir secara berdampingan, khsuusnya di era modernisasi saat ini. Dangke merupakan makanan khas/tradisional dari hasil usaha pengolahan susu yang menjadi makanan turuntemurun dari nenek moyang dan mempunyai rasa yang lezat dan bergizi tinggi. Pemerintah setempat berupaya untuk mengembangkan usaha tersebut antara lain dengan mengakomodir permintaan pasar, penambahan populasi, dan perbaikan sistem pemeliharaan yang terus diintroduksi dan dikembangkan dalam kelembagaan peternak. Sejalan dengan perkembangan ekonomi dan kebutuhan masyarakat yang semakin meningkat, sehingga masyarakat melakukan diversifikasi produk dari membuat dangke menjadi kerupuk dangke. Hal itu dilakukan untuk mendapatkan penghasilan yang tinggi. Pada umumnya satu buah dangke terbuat dari 1,25 - 1,5 liter susu segar dengan harga jual dangke saat ini hanya Rp. 25.000/biji, sementara kerupuk dangke mencapai Rp. $30.000 / \mathrm{kg}$, kemudian untuk menghasilkan $1 \mathrm{~kg}$ kerupuk susu, hanya setara dengan setengah biji dangke. Hal inilah yang mendorong dalam upaya meningkatkan taraf hidup mereka, sekaligus mengurangi tingkat ketergantungan dan tingkat kemiskinan mereka (Yunus \& Sahari, 2019).

Produksi kerupuk dangke merupakan salah satu usaha unggulan daerah di Desa Cendana Kecamatan Cendana Kabupaten Enrekang yang berbahan dasar susu sapi. Kerupuk dangke adalah suatu makanan camilan yang terbuat dari bahan dasar dari dangke, susu sapi dan tepung. Tepung ini umumnya dari ubi kayu, akan tetapi yang dipakai masyarakat Desa Cendana adalah tepung dari beras ketan. Usaha kerupuk dangke dengan menggunakan susu dengan rata-rata produksi 43,5 liter setiap hari, dapat menghasilkan kurang lebih 592 bungkus kerupuk dangke. Biaya produksi kerupuk dangke dengan menggunakan bahan-bahan dan peralatan, sebesar Rp. 1.959.830. Hasil penjualan kerupuk dangke sebanyak 592 bungkus dengan harga Rp. 10.000/ bungkus adalah sebesar Rp. 5.952.000. Selisih harga antara penjualan dan biaya produksi yang merupakan estimasi keuntungan setiap hari sebesar Rp. 3.992.170. Terdapat nilai tambah penghasilan terhadap usaha kerupuk dangke, yaitu sebesar Rp. 3.691.335. Hasil ini memperlihatkan bahwa usaha keripik dangke lebih menguntungkan jika dibandingkan dengan usaha dangke (Abduh \& Mallawangeng, 2018).

Perilaku konsumen dalam mengkonsumsi kerupuk dangke dipengaruhi oleh faktor budaya masyarakat setempat. Konsumsi kerupuk dangke sudah menjadi kebiasaan di kalangan masyarakat Enrekang (Wahyuningsih, Paly, \& Astati, 2017). Konsumen yang semakin selektif dalam menentukan pilihan saat membeli kerupuk dangke, salah satu pemikiran bagi para produsen dalam upaya memaksimalkan kepuasan pelanggan. Pemilihan atribut berkaitan dengan tingkat kepentingan dan kesesuaian produk yang dianggap dapat memuaskan keinginan konsumen.

Pemahaman terhadap atribut yang menjadi pilihan konsumen akan memudahkan para produsen untuk memberikan perhatian lebih terhadap atribut tersebut, sehingga dapat mengubah dan membentuk sikap konsumen lebih positif terhadap kerupuk dangke. Kepuasan pelanggan adalah tingkat perasaan pelanggan setelah membandingkan nilai atribut produk dengan harapannya terhadap nilai atribut produk tersebut. Seorang pelanggan yang memiliki sikap merasa puas terhadap nilai yang diberikan oleh suatu produk, kemungkinan besar menjadi pelanggan dalam waktu yang lama, dan kepuasan pelanggan berpengaruh terhadap angka penjualan yang akhirnya memberikan keuntungan kepada penjual kerupuk dangke.

Sikap konsumen mempunyai peranan penting didalam membentuk perilaku konsumen. Perusahan akan dapat mengetahui kebutuhan dan perilaku konsumen dengan mengetahui sikap konsumen (Tarmizi, 2017). Sikap konsumen sangat berperan dalam membantu perusahaan/industri untuk mengetahui hal-hal yang diinginkan oleh konsumennya. Sikap konsumen merupakan satu faktor penting yang akan mempengaruhi konsumen dalam pengambilan keputusan pembelian terhadap suatu produk. Sikap konsumen muncul, dipengaruhi oleh adanya kepercayaan konsumen dan evaluasi terhadap manfaat suatu produk. Tidak hanya produknya saja yang menjadi pertimbangan konsumen terhadap pembelian, namun juga atribut atau karakteristik yang 
melengkapi produk tersebut (Ilhamudin, Nururly, \& Rusminah, 2019; Sumarwan, 2011).

Berbagai penelitian terdahulu telah dilakukan dalam mengukur atribut produk kerupuk baik kerupuk singkong, kerupuk tempe, kerupuk amplang dan kerupuk ikan antara lain : rasa, warna, harga, bentuk, aroma, kemasan, volume, warna, kemudahan memperoleh, bau, tekstur, kegosongan, berminyak, gurih, kepahitan, keasinan, kerenyahan, getas, ketebalan, ketengikan, langu (Anhar \& Wardanu, 2016; Febrianto, Restuhadi, \& Rossi, 2017; Harsita \& Amam, 2019; Wahyuni, Nurliza, \& Kurniati, 2017). Sementara itu, atribut yang digunakan untuk mengukur tingkat kepuasan konsumen terhadap kerupuk dangke merek Nursi di Desa Talaga Kecamatan Enrekang di Kabupaten Enrekang adalah kemasan, rasa, variasi rasa, ukuran, dan harga (Wahyuningsih et al., 2017). Berdasarkan hal tersebut, maka atribut yang digunakan dalam penelitian ini yaitu : rasa, aroma,tekstur, kemasan dan harga.

Berdasarkan fenomena-fenomena tersebut maka penelitian ini diharapkan dapat mengetahui posisi daya saing kerupuk dangke yang beredar di wilayah Kecamatan Cendana dilihat dari sudut pandang melalui perbandingan sikap konsumen terhadap atribut produk kerupuk dangke bermerek dan tidak bermerek. Tujuan penelitian ini adalah untuk menganalisis sikap konsumen terhadap kerupuk dangke merek Melona dan tanpa merek di Kecamatan Cendana, Kabupaten Enrekang.

\section{Materi dan Metode}

\subsection{Tempat dan Waktu Penelitian}

Penelitian ini dilakukan pada rumah produksi kerupuk dangke Melona Baba (bermerek) dan rumah produksi kerupuk dangke tanpa merek di dusun Baba, desa Cendana, Kecamatan Cendana Kabupaten Enrekang mulai bulan Agustus sampai Oktober 2020. Penentuan lokasi penelitian dilakukan secara purposive berdasarkan pertimbangan bahwa di Kecamatan Cendana Kabupaten Enrekang merupakan salah satu daerah yang memproduksi kerupuk dangke dan memiliki jumlah populasi sapi perah terbanyak diantara kecamatan lainnya.

\subsection{Populasi dan Sampel}

Populasi dalam penelitian ini adalah seluruh konsumen kerupuk dangke baik merek Melona dan tanpa merek. Penentuan sampel dalam penelitian ini menggunakan teknik accidental sampling (teknik sampling kebetulan) yaitu siapa saja yang secara kebetulan bertemu dengan peneliti dapat digunakan sebagai sampel, bila pandangan orang yang kebetulan ditemui itu cocok sebagai responden. Jumlah sampel yang diambil dalam penelitian ini adalah 50 responden selama kurang lebih satu bulan, karena jumlah konsumen tidak teridentifikasi maka jumlah sampel ditetapkan sebanyak 50 responden (Simarmata, Osak, Endoh, \& Oroh, 2019). Sampel dalam penelitian ini adalah konsumen yang singgah membeli dan mencoba kerupuk dangke Merek Melona dan kerupuk dangke tanpa merek di Kecamatan Cendana Kabupaten Enrekang yang berada pada rentan usia $16-55$ tahun, dipilihnya responden penelitian pada selang usia 16 - 55 tahun dengan pertimbangan bahwa pada rentang usia tersebut merupakan rentang usia dari konsumen potensial seperti diketahui penduduk dengan usia diatas 55 tahun telah memasuki usia lanjut dan dari segi pola makan jarang mengkonsumsi jenis makanan kerupuk dangke.

\subsection{Analisis Data}

Analisis data yang digunakan dalam penelitian ini yaitu analisis Multiatribut Fishbein. Model Fishbein menggambarkan bahwa sikap konsumen terhadap suatu produk atau merek sebuah produk ditentukan oleh dua hal yaitu (1) kepercayaan (belief) terhadap suatu atribut yang dimiliki produk atau merek (komponen $b_{i}$ ) dan evaluasi (evaluation) pentingnya atribut dari produk tersebut (komponen $e_{i}$ ). Atribut yang digunakan dalam penelitian ini antara lain : rasa, aroma, tekstur, harga dan kemasan (Widiyanti, 2019).

\section{Rumus Multiatribut Fishbein:}

$$
A_{0}=\sum_{i=1}^{n} b i . e i
$$

Keterangan:

$$
\begin{aligned}
A_{0}= & \text { Sikap Konsumen terhadap kerupuk } \\
& \text { dangke } \\
b_{i}= & \begin{array}{l}
\text { Kekuatan kepercayaan bahwa kerupuk } \\
\text { dangke tersebut memiliki atribut } \mathrm{i}
\end{array} \\
e_{i}= & \begin{array}{l}
\text { Dimensi evaluasi konsumen terhadap } \\
\text { atribut } \mathrm{i}
\end{array} \\
\mathrm{n}= & \begin{array}{l}
\text { Jumlah atribut yang digunakan dimiliki } \\
\text { objek }
\end{array}
\end{aligned}
$$

\section{Multiatribut Fishbein}

Analisis Multiatribut Fishbein dilakukan dengan langkah-langkah berikut: 
1. Menentukan atribut karena setiap produk memiliki banyak atribut, dan semuanya bisa menentukan sikap seseorang maka angkah pertama yang dilakukan adalah menemukan atribut yang menonjol di pasar target.

2. Menentukan penilaian kepercayaan terhadap atribut kerupuk dangke (komponen $b_{i}$ ) dengan cara menentukan standar penilaian (skoring) dengan skala likert. Skala likert berhubungan dengan pernyataan tentang sikap responden terhadap atribut. Skor kepercayaan terhadap atribut kerupuk dangke dengan skala likert dapat dilihat pada Tabel 1.

3. Menentukan evaluasi mengenai atribut (komponen $e_{i}$ ) dengan menentukan standart penilaian (skoring) dengan menggunakan skala likert, kemudian skor masing-masing atribut dikalikan dengan frekuensi jawaban responden dan dibagi dengan jumlah responden untuk mengetahui nilai evaluasi konsumen terhadap atribut Kerupuk dangke.

4. Mengukur sikap terhadap atribut produk yaitu dengan cara mengalikan skor tingkat kepercayaan (komponen $b_{i}$ ) rata-rata dengan skor tingkat kepentingan (komponen $e_{i}$ ) ratarata sehingga didapat nilai sikap konsumen $\left(A_{0}\right)$ terhadap objek konsumen terhadap kerupuk dangke secara keseluruhan.

Tabel 1. Skor kepercayaan terhadap atribut kerupuk dangke

\begin{tabular}{lc}
\hline Kriteria & Skor \\
\hline Sangat puas & 5 \\
Puas & 4 \\
Netral & 3 \\
Tidak puas & 2 \\
Sangat tidak puas & 1 \\
\hline
\end{tabular}

\section{Hasil dan Pembahasan}

\subsection{Karakteristik Responden}

Karakteristik responden penelitian berdasarkan jenis kelamin, umur, pendidikan, pekerjaan dan pendapatan konsumen yang membeli produk kerupuk dangke sebanyak 50 orang dapat dilihat pada Tabel 2 .

Tabel 2 menunjukkan bahwa umumnya konsumen yang membeli kerupuk dangke terbanyak adalah berjenis kelamin perempuan dengan persentase sebesar $76 \%$ dan laki-laki sebesar $24 \%$. Jumlah responden perempuan dalam penelitian ini lebih banyak dibandingkan laki-laki. Hal ini dapat diasumsikan karena dalam sebuah rumah tangga yang memahami masalah-masalah yang berkaitan dengan urusan konsumsi keluarga dan mengambil keputusan khususnya dalam pembelian kerupuk dangke adalah perempuan. Hal tersebut didukung oleh pendapat Priambodo \& Najib (2014) yang menyatakan bahwa di indonesia terdapat kecenderungan peran perempuan yang tinggi dalam proses pengambilan keputusan rumah tangga yang berkaitan dengan kebutuhan pokok. Sementara berdasarkan umur konsumen yang membeli produk kerupuk dangke umumya berkisar 26-35 tahun dimana konsumen mampu mengambil keputusan berbelanja produk kerupuk dangke.

Tabel 2. Karakteristik responden

\begin{tabular}{lcc}
\hline $\begin{array}{l}\text { Karakteristik } \\
\text { responden }\end{array}$ & $\begin{array}{c}\text { Jumlah } \\
\text { (orang) }\end{array}$ & $\begin{array}{c}\text { Persentase } \\
\text { (\%) }\end{array}$ \\
\hline $\begin{array}{l}\text { Jenis Kelamin } \\
\text { Laki-laki }\end{array}$ & 12 & 24 \\
Perempuan & 38 & 76 \\
Umur & & \\
16-25 tahun & 17 & 34 \\
26-35 tahun & 21 & 42 \\
36-45 tahun & 7 & 14 \\
46-55 tahun & 5 & 10 \\
Pekerjaan & & \\
ASN & 13 & 26 \\
Honorer & 8 & 16 \\
Petani & 4 & 8 \\
Peternak & 3 & 6 \\
IRT & 7 & 14 \\
Mahasiswa (siswa) & 15 & 30 \\
Pendapatan & & \\
500.000-1.000.000 & 14 & 28 \\
1.100.000-1.500.000 & 12 & 24 \\
1.600.000-2.000.000 & 9 & 18 \\
2.100.000-2.500.000 & 15 & 30 \\
\hline Sumber: Data primer yang telah diolah, 2020
\end{tabular}

Berdasarkan tingkat pendidikan terlihat bahwa umumnya konsumen yang membeli kerupuk dangke terbanyak adalah mahasiswa dengan persentase sebesar $30 \%$ disusul ASN sebesar 26\%. Hal ini disebabkan karena konsumen sebagian besar melakukan praktek lapang di wilayah Kecamatan Cendana. Disamping itu, pendapatan sangat berperan penting bagi rumah tangga, oleh karena itu pendapatan dapat mempengaruhi keputusan dalam konsumsi rumah tangga. Besarnya jumlah pendapatan akan menggambarkan besarnya daya beli dari konsumen. Tabel 2 menunjukkan bahwa pendapatan rata-rata per bulan responden sangatlah beragam. Hal ini sesuai dengan penelitian yang dilaporkan oleh Setiabudi, Parera, \& Far-Far (2013) bahwa responden yang membeli dan mengkonsumsi sayuran segar didominasi oleh responden dari kalangan menengah ke atas. Besarnya tingkat pendapatan responden akan menjadi bahan pertimbangan 
dalam proses pengambilan keputusan pembelian dan pola konsumsi sehingga mempengaruhi daya beli responden sayuran segar. Selain itu, tingkat pendapatan merupakan salah satu faktor yang menentukan life style masyarakat.

\subsection{Multiatribut Fishbein}

Model Multiatribut Fishbein dapat mengukur sikap terhadap atribut produk dengan keputusan akhir untuk membeli atau tidak. Elemen utama dari model ini yaitu kekuatan kepercayaan/keyakinan, dimana kemungkinan diyakini dari hubungan antara suatu objek dengan ciri-ciri yang relevan dan evaluasi yaitu mencerminkan seberapa baik konsumen menilai suatu ciri (Anggiasari, Indriani, \& Endaryanto, 2016). Data yang dibutuhkan untuk menghasilkan sikap konsumen adalah nilai keyakinan/kepercayaan konsumen $\left(b_{i}\right)$ dan evaluasi konsumen $\left(e_{i}\right)$.

\subsection{Komponen Evaluasi Kepentingan}

Tingkat kepentingan disimbolkan $e_{i}$ yang berfungsi sebagai pengukur seberapa penting sebuah atribut bagi seorang konsumen dalam menilai sebuah produk. Nilai tingkat kepentingan ini berkisar direntang $1-5$ yang mengacu pada skala likert, dimana nilai 1 diartikan sebagai sangat tidak penting, 2 tidak penting, 3 biasa saja, 4 penting dan 5 sangat penting. Tingkat kepentingan ini diperoleh dari hasil kuisioner yang isi pertanyaannya sama untuk dua produk kerupuk dangke yaitu kerupuk dangke merek Melona dan kerupuk dangke tanpa merek mengenai atribut rasa, aroma, tekstur, harga dan kemasan yang hasilnya dapat dilihat pada Tabel 3.

Tabel 3.Komponen evaluasi kepentingan konsumen terhadap kerupuk dangke merek Melona dan tanpa merek di Kecamatan Cendana, Enrekang.

\begin{tabular}{lc}
\hline Atribut $(i)$ & $\begin{array}{c}\text { Tingkat kepentingan kerupuk dangke } \\
(\mathrm{ei})\end{array}$ \\
\hline Rasa & 4,46 \\
Aroma & 3.24 \\
Tekstur & 4,24 \\
Harga & 3,36 \\
Kemasan & 3,44 \\
\hline
\end{tabular}

Sumber: Data primer setelah diolah (2020)

Berdasarkan Tabel 3 dapat diperoleh data bahwa yang menempati posisi utama dalam tingkat kepentingan konsumen kerupuk dangke adalah atribut rasa sebesar 4,46 yang artinya konsumen menganggap bahwa rasa merupakan suatu hal yang penting dalam sebuah produk kerupuk dangke. Hal ini didukung oleh Wahyuningsih et al. (2017) yang mengemukakan bahwa bagi konsumen variasi rasa setiap produk kerupuk dangke merek Nursi sangat enak dan memiliki rasa yang unik serta berbeda dengan kerupuk keju lainnya. Rasa balado merupakan variasi rasa yang paling banyak dipilih oleh konsumen karena memiliki rasa yang enak dan gurih. Konsumen akan merasa puas jika produk tersebut sesuai dengan harapannya dan selanjutnya akan meningkatkan permintaan atau pembelian dari produk tersebut. Disamping itu, atribut lainnya menempati posisi kedua adalah atribut tekstur yakni sebesar 4,2, posisi ketiga dengan nilai sebesar 3,44 yaitu kemasan. Posisi keempat dan kelima adalah harga dan aroma dengan nilai $e_{i}$ sebesar 3,36 dan 3,24. Tingkat kepentingan yang dinilai oleh konsumen berbeda menurut besarnya skor evaluasi yang diperoleh. Semakin tinggi skor evaluasi yang diperoleh maka semakin penting suatu atribut.

\subsection{Komponen Kepercayaan}

Tingkat kepercayaan konsumen terhadap sebuah atribut sangat penting dalam strategi pemasaran. Kepercayaan adalah kekuatan konsumen bahwa suatu produk kerupuk dangke memiliki atribut tertentu yang melengkapinya. Dimensi kedua dari variabel sikap konsumen adalah evaluasi tingkat kepercarayaan terhadap 5 atribut kerupuk dangke. Variabel ini juga menggambarkan bagaimana konsumen menilai tingkat kepercayaan (believe) dari 5 atribut yaitu rasa, aroma, tekstur, harga dan kemasan yang selanjutnya diukur dengan skala likert. Komponen kepercayaan produk kerupuk dangke dapat dilihat pada Tabel 4

Tabel 4.Komponen kepercayaan konsumen terhadap kerupuk dangke merek Melona dan tanpa merek di Kecamatan Cendana, Enrekang.

\begin{tabular}{lcc}
\hline Atribut $(i)$ & $\begin{array}{c}\text { Merek Melona } \\
\left(b_{i 1}\right)\end{array}$ & $\begin{array}{c}\text { Tanpa } \\
\text { Merek }\left(b_{\mathrm{i} 2}\right)\end{array}$ \\
\hline Rasa & 4,22 & 4,02 \\
Aroma & 2,92 & 2,86 \\
Tekstur & 4,06 & 3,84 \\
Harga & 2,94 & 3,68 \\
Kemasan & 3,98 & 2,68 \\
\hline
\end{tabular}

Sumber: Data primer setelah diolah (2020)

Tabel 4 menunjukkan nilai rataan kepercayaan konsumen terhadap kelima atribut kerupuk dangke merek Melona dan kerupuk dangke tanpa merek. Berdasarkan tabel tersebut menunjukkan bahwa rasa memiliki nilai rataan 
tertinggi dalam kategori kepercayaan konsumen terhadap kerupuk dangke yaitu sebesar 4,22 untuk kerupuk dangke Merek Melona dan 4,02 untuk kerupuk dangke tanpa merek. Hal ini berarti bahwa rasa pada merek Melona maupun tanpa merek yang tinggi mendapatkan tanggapan yang sangat positif dari konsumen. Kerupuk dangke yang diproduksi di Kecamatan Enrekang bervariasi mulai dari rasa original, coklat dan balado. Variasi produk utamanya terhadap cita rasa dari kerupuk dangke, akan dihasilkan produksi meningkat dari banyak variasi pilihan konsumen dan sekaligus dapat meningkatkan penghasilan peternak sekaligus pengolah kerupuk dangke (Abduh \& Mallawangeng, 2018). Apabila dikaitkan dengan tingkat kepentingan konsumen sebelumnya juga menunjukkan bahwa rasa dari kerupuk dangke merupakan alasan utama dalam memilih dan membeli kerupuk dangke di Kecamatan Cendana. Adapun atribut dengan rataan terendah pada kerupuk dangke merek Melona adalah aroma. Hal ini menunjukan bahwa atribut aroma bukan menjadi bahan pertimbangan konsumen dalam menentukan pilihan. Atribut dengan nilai paling rendah pada kerupuk dangke tanpa merek adalah kemasan dengan nilai 2,68. Hal ini sangat berbeda dengan kerupuk dangke Merek Melona dimana atribut kemasan dengan nilai 3,98 artinya kemasan memberikan pengaruh yang cukup kuat dalam menentukan pilihan konsumen pada kerupuk dangke Merek Melona. Kemasan produk sangat penting sebagai penampilan produk yang menarik perhatian konsumen dan terjamin higienis. Hal ini sejalan dengan hasil penelitian Hiola \& Aisyah (2017) bahwa tampilan kemasan secara keseluruhan dapat menjadi pertimbangan bagi responden untuk memutuskan pembelian dalam pergeseran pangsa pasar produk.

\subsection{Sikap Konsumen terhadap Kerupuk Dangke}

Sikap merupakan salah satu konsep yang paling penting digunakan pemasaran untuk memahami konsumen dan faktor penting yang akan memengaruhi keputusan konsumen. Konsep sikap sangat terkait dengan konsep kepercayaan dan perilaku (behavior). Penilaian sikap konsumen terhadap atribut-atribut kerupuk dangke dapat dihitung berdasarkan nilai rataan dari evaluasi kepentingan $\left(e_{i}\right)$ dan kepercayaan atribut $\left(b_{i}\right)$ yaitu dengan mengalikan kedua variabel. Apabila nilai sikap untuk masingmasing atribut dijumlahkan maka akan diperoleh nilai sikap $\left(A_{o}\right)$ secara keseluruhan untuk kerupuk dangke. Berdasarkan hasil penelitian mengenai tingkat kepercayaan dan tingkat kepentingan yang telah diuraikan diatas, maka dapat ditentukan analisis sikap konsumen terhadap kerupuk dangke yang dapat dilihat pada Tabel 5

Tabel 5. Sikap konsumen terhadap kerupuk dangke merek Melona dan tanpa merek di Kecamatan Cendana, Enrekang.

\begin{tabular}{lcc}
\hline Atribut $(i)$ & $\begin{array}{c}\text { Kerupuk } \\
\text { Dangke Merek } \\
\text { Melona } \\
\left(A_{01}\right)\end{array}$ & $\begin{array}{c}\text { Kerupuk } \\
\text { Dangke Tanpa } \\
\text { Merek }\left(A_{02}\right)\end{array}$ \\
\hline Rasa & 18,82 & 17,92 \\
Aroma & 9,46 & 9,26 \\
Tekstur & 17,21 & 16,28 \\
Harga & 9,2 & 12,36 \\
Kemasan & 13,69 & 9,21 \\
\hline$\sum \mathrm{b}_{\mathrm{i}} \mathrm{x} \mathrm{e}_{\mathrm{i}}$ & 68,38 & 65,03 \\
\hline
\end{tabular}

Sumber: Data primer setelah diolah (2020)

Berdasarkan Tabel 5 menunjukkan bahwa sikap konsumen terhadap kelima atribut produk secara keseluruhan yaitu atribut rasa dan tekstur berturut-turut menempati posisi pertama dan kedua baik pada kerupuk dangke merek Melona maupun kerupuk dangke tanpa merek. Oleh karena itu, sikap konsumen pada keseluruhan kerupuk dangke bergantung pada kualitas rasa dan tekstur atau kerenyahan dari kerupuk dangke. Sikap konsumen pada atribut aroma untuk kedua produk juga hampir sama. Nilai untuk atribut aroma yakni 9,46 kerupuk dangke Merek Melona dan 9,26 untuk kerupuk dangke tanpa merek. Nilai yang hampir seimbang walaupun penilaian untuk kerupuk dangke Merek Melona sedikit lebih tinggi. Artinya sikap konsumen terhadap aroma kedua produk kerupuk dangke adalah sama-sama positif. Hal ini sesuai dengan Wahyuningsih et al. (2017) responden menyatakan sangat puas dengan rasa produk kerupuk Dangke merek Nursi. Sebanyak $50 \%$ menyatakan kepuasannya terhadap rasa dari kerupuk Dangke karena menurut mereka rasa dari kerupuk Dangke merek Nursi enak, gurih dan sesuai dengan selera dari masyarakat Desa Talaga. Dalam teori perilaku konsumen, kualitas dari atribut suatu produk berperan penting dalam menentukan keputusan pembelian. Contohnya jika produk memiliki rasa yang enak dan sesuai dengan selera konsumen maka konsumen akan melakukan pembelian secara berulang. Atribut aroma bukanlah merupakan penilaian penting bagi konsumen dalam menentukan pilihan. Atribut rasa 
memiliki nilai kepentingan tertinggi, atribut rasa merupakan atribut yang paling dipertimbangkan konsumen sebelum melakukan pembelian. Sementara, aroma berada pada posisi terakhir dimana khas pada jamur tiram goreng preferensi konsumen ialah Jamur tiram goreng dengan aroma khas sedang, karena aroma khas yang sedang memiliki tingkat bau langu yang lebih rendah dibandingkan aroma khas yang kuat (Rajasa, 2019).

Pada atribut harga, kerupuk dangke tanpa merek lebih murah jika dibandingkan kerupuk dangke merek Melona. Selanjutnya adalah atribut kemasan. Pada atribut kemasan tampak adanya perbedaan mencolok untuk kedua produk. Kerupuk dangke merek melona dengan nilai 13,69 sedangkan kerupuk dangke tanpa merek dengan nilai 9,21. Sikap konsumen lebih positif terhadap atribut kemasan kerupuk dangke merek Melona. Tampilan kemasan dengan label yang menarik menjadi nilai tambah dan daya tarik tersendiri bagi para konsumen.

Berdasarkan hasil penelitian diketahui bahwa sebagian besar konsumen membeli kerupuk dangke untuk dijadikan oleh-oleh sehingga kerupuk dangke Merek Melona lebih banyak dipilih oleh responden dibanding kerupuk dangke tanpa merek. Kemasan yang menarik dan berbeda dari merek lain menyebabkan harga kerupuk dangke merek Melona sedikit lebih mahal jika dibandingkan dengan produk kerupuk dangke tanpa merek. $\mathrm{Hal}$ ini menyebabkan beberapa konsumen memilih kerupuk dangke tanpa merek karena harganya yang relative lebih murah dibanding kerupuk dangke merek melona dengan perbedaan angka yaitu 9,20 untuk kerupuk dangke merek Melona dan 12,36 untuk kerupuk dangke tanpa merek. Namun mayoritas konsumen membeli untuk dijadikan oleh-oleh sehingga kerupuk dangke dengan kemasan yang menarik tetap menjadi pilihan dan tidak memikirkan masalah harga dari kerupuk dangke itu sendiri. Hal ini didukung oleh penelitian Aisyah \& Hiola (2017b) pemilihan merek yang dilakukan oleh konsumen pada umumnya di pengaruhi oleh harga yang terjangkau, kemasan, aroma dan proses label produk.

Berdasarkan hasil nilai sikap keseluruhan konsumen diatas dapat diketahui bahwa nilai sikap keseluruhan $\left(A_{o}\right)$ untuk kerupuk dangke Merek Melona sebesar 68,38 sedangkan nilai sikap keseluruhan $\left(A_{o}\right)$ untuk kerupuk dangke tanpa merek sebesar 65,03. Hal tersebut menunjukan bahwa secara keseluruhan sikap konsumen lebih positif pada kerupuk dangke merek Melona dibanding kerupuk dangke tanpa merek. Pada penelitian ini konsumen menyikapi kerupuk dangke Merek Melona dianggap lebih baik karena memiliki rasa, tekstur dan aroma yang enak yang dikemas dalam bentuk yang menarik serta dengan harga yang cukup terjangkau dan sangat pantas dibeli oleh konsumen sebagai oleh-oleh makanan khas unggulan dari kabupaten Enrekang. Hal ini sejalan dengan hasil penelitian Aisyah \& Hiola (2017a) menunjukkan atribut-atribut produk yang menjadi preferensi konsumen atau yang lebih disukai oleh konsumen yaitu harga, aroma yang dominan ayam dan bumbu, berlabel SNI dan memiliki kemasan ukuran sedang. Lebih lanjut, yang menjadi pertimbangan utama sampai terakhir oleh konsumen pada saat membeli produk olahan ayam adalah yang pertama dari faktor harga, kedua faktor kemasan, ketiga faktor aroma, dan keekmpat faktor label yang menjadi faktor terakhir dalam penelitian ini.

\section{Kesimpulan}

Atribut unggulan dari kerupuk dangke berbeda dengan produk lain yakni atribut kemasan. Kerupuk dangke Melona dikemas secara modern sementara kerupuk dangke tanpa merek dikemas secara sederhana. Kemasan merupakan identitas produk kerupuk dangke dalam menjaga kualitas produk itu sendiri. Dengan demikian secara keseluruhan konsumen lebih puas terhadap produk kerupuk dangke Merek Melona dari pada produk kerupuk dangke tanpa merek. Produsen kerupuk dangke tanpa merek perlu meningkatkan kualitas berdasarkan prioritas dalam hal rasa, aroma, harga, tekstur dan tampilan kemasan demi mendapatkan kepercayaan konsumen jangka panjang.

\section{Daftar Pustaka}

Abduh, M. N., \& Mallawangeng, T. (2018). Analisis pengembangan usaha keripik dangke di Kabupaten Enrekang. Jurnal Dedikasi, 20(1), 56-64.

Aisyah, R. St., \& Hiola, S. K. Y. (2017a). Analisis preferensi konsumen terhadap produk olahan ayam di Kota Makassar. Jurnal Galung Tropika, 6(3), 174-184.

Aisyah, R. St., \& Hiola, S. K. Y. (2017b). Pergeseran pangsa pasar produk nugget ayam di Kota Makassar. In Firman (Ed.), Seminar Nasional Hasil Penelitian (SNP2M) (pp. 13-18). Makassar: Pusat Penelitian \& Pengabdian Kepada Masyarakat (P3M), Politeknik Negeri Ujung Pandang. 
Anggiasari, N. M., Indriani, Y., \& Endaryanto, T. (2016). Sikap dan pengambilan keputusan pembelian sayuran organik oleh konsumen di Kota Bandar Lampung. Jurnal Ilmu-Ilmu Agribisnis, 4(4), 391-397.

Anhar, M., \& Wardanu, A. P. (2016). Analisa preferensi konsumen terhadap kerupuk amplang produksi Toko OBIC di Kabupaten Ketapang. Jurnal Sistem Teknik Industri, 18(1), 6-11.

Febrianto, W. E., Restuhadi, F., \& Rossi, E. (2017). Analisis pemetaan kesukaan konsumen pada produk keripik tempe original di kalangan mahasiswa Fakultas Pertanian Universitas Riau. Jurnal Online Mahasiswa Fakultas Pertanian Universitas Riau, 4(2), 1-13.

Harsita, P. A., \& Amam. (2019). Analisis sikap konsumen terhadap atribut olahan singkong. Agrisocionomics: Jurnal Sosial Ekonomi Pertanian, 3(1), 19-27. https://doi. org/10.14710/agrisocionomics.v3i1.2469

Hiola, S. K. Y., \& Aisyah, R. St. (2017). Pergeseran pangsa pasar produk susu fermentasi bermerek dalam kemasan di Kota Makasar. Agriekonomika: Jurnal Sosial Ekonomi dan Kebijakan Pertanian, 6(1), 6271.

Ilhamudin, M., Nururly, S., \& Rusminah. (2019). Sikap konsumen terhadap tahu Abian Tubuh sebagai produk unggulan sektor makanan Kota Mataram. JMM UNRAM: Jurnal Magister Manajemen Universitas Mataram, 8(1), 35-45. https:// doi.org/10.29303/jmm.v8i1.353

Priambodo, L. H., \& Najib, M. (2014). Analisis kesediaan membayar (willingness to pay) sayuran organik dan faktor-faktor yang mempengaruhinya. Jurnal Manajemen dan Organisasi, 5(1), 1-14. https://doi.org/10. 29244/jmo.v5i1.12125

Priyanto, D. (2018). Prospek pengembangan sapi perah di luar Pulau Jawa (Kasus di Provinsi Sumatera Barat). Prosiding Seminar Teknologi dan Agribisnis Peternakan VI: Pengembangan Sumber Daya Genetik Ternak Lokal Menuju Swasembada Pangan Hewani ASUH, 6, 131-139. Purwokerto: Fakultas Peternakan Universitas Jenderal Soedirman.

Rajasa, M. A. (2019). Analisis preferensi konsumen terhadap produk olahan jamur tiram (Pleorotus ostreatus) di Kota Medan. Universitas
Sumatera Utara.

Setiabudi, M. U., Parera, W. B., \& Far-Far, R. A. (2013). Proses pengambilan keputusan konsumen dalam pembelian sayuran segar studi kasus Hypermart Ambon City Center Kota Ambon. Agrilan, 1(4), 25-40.

Simarmata, L., Osak, R. E. M. F., Endoh, E. K. M., \& Oroh, F. N. S. (2019). Analisis preferensi konsumen dalam membeli daging di pasar tradisional Kota Manado (Studi kasus "Pasar Pinasungkulan Karombasan"). Zootec, 39(2), 194-202. https://doi.org/10.35792/zot.39.2.2019.2 4427

Sumarwan, U. (2011). Perilaku Konsumen: Teori dan Penerapannya dalam Pemasaran. Jakarta: PT Ghalia Indonesia.

Suyudi, Nuryaman, H., \& Erfan. (2016). Strategi dan model pengembangan usaha peternakan sapi rancah. Jurnal Riset Agribisnis dan Peternakan, 1(2), 25-36.

Tarmizi, A. (2017). Analisis sikap konsumen terhadap keputusan pembelian produk sepeda motor Honda merek Vario pada PD. Daya Motor Sungai Bahar Muaro Jambi. Ekonomis: Journal of Economics and Business, 1(1), 18-31. https://doi.org/10. 33087/ekonomis.v1i1.4

Wahyuni, T., Nurliza, \& Kurniati, D. (2017). Preferensi konsumen terhadap pembelian kerupuk ikan di Kota Sintang. Jurnal Social Economic of Agriculture, 6(1), 101-108. https: //doi.org/10.26418/j.sea.v6i1.21592

Wahyuningsih, Paly, M. B., \& Astati. (2017). Analisis tingkat kepuasan konsumen terhadap produk dan harga kerupuk dangke merek Nursi di Kabupaten Enrekang (Studi kasus di Desa Telaga). Jurnal Ilmu dan Industri Peternakan, 3(1), 102-121.

Widiyanti, W. (2019). Sikap konsumen terhadap multiatribut produk Domino pizza dengan metode Fishbein di Depok. Cakrawala: Journal Humaniora Bina Sarana Informatika, 19(1), 107-112.

Yunus, A. T., \& Sahari. (2019). Pengolahan kerupuk dangke pada kelompok usaha. Jurnal Pengabdian Bina Ukhuwah, 1(2), 129133. 